\title{
HUBUNGAN KETERSEDIAAN DAN KESUKAAN DENGAN KONSUMSI BUAH DAN SAYUR PADA MAHASISWA POLTEKKES KEMENKES TASIKMALAYA
}

\section{RELATIONSHIP BETWEEN AVAILABILITY AND PREFERENCE WITH FRUIT AND VEGETABLE CONSUMPTION AMONG POLTEKKES KEMENKES TASIKMALAYASTUDENTS}

\author{
Irma Nuraeni ${ }^{1^{*}}$, Naning Hadiningsih ${ }^{2}$ \\ ${ }^{1,2}$ Poltekkes Kemenkes Tasikmalaya, Indonesia \\ email: ${ }^{*}$ irma_nuraeni20@yahoo.com, ${ }^{2}$ nhadiningsih@gmail.com
}

\begin{abstract}
ABSTRAK
Berdasarkan laporan riset kesehatan dasar nasional pada tahun 2007 dan 2013 menunjukkan masih tingginya proporsi perilaku konsumsi kurang buah dan atau sayur. Tujuan penelitian ini adalah untuk mengetahui hubungan ketersediaan dan kesukaan dengan konsumsi buah dan sayur pada Mahasiswa Poltekkes Kemenkes Tasikmalaya. Jenis Penelitian ini adalah observasional dengan desain cross sectional. Sampel penelitian ini sebanyak 108 Mahasiswa, dengan teknik proporsional stratified random sampling. Variabel konsumsi buah sayur diukur menggunakan Semi Kuantitatif Food Frequency Questionnare, sedangkan ketersediaan dan kesukaan menggunakan kuesioner terstruktur. Analisis data menggunakan chi square test. Hasil penelitian menunjukkan bahwa sebanyak 61,1 \% mahasiswa Poltekkes Kemenkes Tasikmalaya mengonsumsi buah dan sayur sesuai anjuran ( $\geq 400$ gram) dan sebanyak $38,9 \%$ belum sesuai anjuran ( $\geq 400 \mathrm{gram}$ ). Tidak adanya hubungan antara kesukaan dengan konsumsi buah dan sayur ( $p$ value $=0,05$ ). Adanya hubungan antara ketersediaan dengan konsumsi buah dan sayur pada mahasiswa Poltekkes Kemenkes Tasikmalaya ( $p$ value $=0,00$ ).
\end{abstract}

Kata Kunci : Ketersediaan, Kesukaan, Konsumsi Buah Sayur

\begin{abstract}
Based on the national basic health research report in 2007 and 2013, there was still a high proportion of national consumption behavior of less fruits and or vegetables. The purpose of this study was to determine the relationship of availability and preferences with fruit and vegetable consumption among Poltekkes Kemenkes Tasikmalaya Students. This type of research was observational with a cross sectional design. The sample of this study was 108 students, using proportional stratified random sampling technique. Variable consumption of fruits and vegetable fruits were measured using Semi Quantitative Food Frequency Questionnaire, while availability and preference using structured questionnaires. Data analysis using chi square test. The results showed that $61.1 \%$ of Tasikmalaya Ministry of Health Polytechnic Students consumed fruit and vegetables according recommendation ( $\geq 400 \mathrm{gram}$ ) and as much as $38.9 \%$ not yet as recommended ( $\geq 400$ grams). There was no relationship between the preference for fruit and vegetable consumption ( $p$ value $=0.05$ ). There was a relationship between availability and consumption of fruit and vegetables among Poltekkes KemenkesTasikmalaya students ( $p$ value $=0,00)$.
\end{abstract}

Keywords : Availability, Preference, Fruits and Vegetables Consumption 


\section{PENDAHULUAN}

Konsumsi sayuran dan buah-buahan yang cukup merupakan salah satu indikator sederhana gizi seimbang. ${ }^{1}$ Konsumsi buah dan sayur yang tinggi merupakan indikator makan sehat dan faktor protektif terhadap penyakit tidak menular. $^{2}$

Berdasarkan laporan riset kesehatan dasar nasional pada tahun 2007 dan 2013 menunjukkan masih tingginya proporsi rerata nasional perilaku konsumsi kurang buah dan atau sayur pada penduduk umur lebih dari 10 tahun, yaitu sebesar 93,5 \% dan 93,6\%. Begitu pula dengan hasil Studi Diet Total Survei Konsumsi Makanan Individu Indonesia Tahun 2014, menunjukkan bahwa rerata konsumsi sayur dan olahannya penduduk Indonesia sebesar 57,1 gram per orang per hari, sedangkan berdasarkan kelompok umur 19 - 55 tahun rerata konsumsi kelompok sayur dan olahannya sebesar 64,5 gram per orang per hari. Rerata konsumsi buahbuahan dan olahannya untuk penduduk Indonesia terlihat masih rendah yaitu 33,5 gram per orang per hari. ${ }^{5}$

Konsumsi buah dan sayur dipengaruhi oleh berbagai faktor lingkungan diantaranya lingkungan budaya, lingkungan fisik, lingkungan sosial dan faktor individu. Ketersediaan buah dan sayur di rumah / sekolah merupakan bagian dari lingkungan fisik. $^{6}$ Ketersediaan merupakan satu-satunya faktor prediktor yang signifikan terhadap konsumsi buah dan sayur. Jenis makanan yang tersedia mempunyai peluang yang lebih besar untuk dikonsumsi, sehingga perlunya upaya penyediaan buah dan sayur di rumah, di sekolah dan area sekitarnya dalam rangka peningkatan jenis makanan ini. ${ }^{7}$

Kesukaan merupakan salah satu faktor individu yang mempengaruhi konsumsi. ${ }^{6}$ Hasil penelitian menyebutkan bahwa pemilihan makanan didasari oleh berbagai kriteria, salah satunya adalah preferensi / kesukaan. Masing-masing individu memiliki perbedaan dalam hal kesukaan. Ada beberapa orang yang menyukai berbagai macam variasi makanan, namun ada beberapa yang terlalu pemilih (picky eaters). Terdapat beberapa perbedaan biologis yang mendasari penerimaan terhadap rasa yang disebabkan pengalaman mengonsumsi / kebiasaan dari sejak kecil hingga dewasa. Ketika kita mengonsumsi makanan, otak akan menerima sinyal dari berbagai organ sensori seperti visual, olfaktori dan sebagainya yang kemudian informasi tersebut akan diintegrasikan menjadi presepsi akhir terhadap makanan.

Konsumsi buah dan sayuran setiap hari penting untuk kesehatan dan kebutuhan zat gizi untuk manusia karena mengandung vitamin, mineral, zat gizi mikro, serat, protein nabati dan komponen biofungsional. Kondisi kesehatan yang buruk, terkait dengan konsumsi buah dan sayuran yang tidak memadai dan kurangnya aktivitas fisik, mendukung pengembangan penyakit tidak menular, obesitas dan kekurangan gizi mikro dan vitamin. Konsumsi buah dan sayuran yang rendah sering dikaitkan dengan pola makan yang tidak sehat di negara maju dan kemiskinan serta kerawanan pangan di negara berkembang. ${ }^{9}$

Penelitian ini merupakan kelanjutan dari hasil penelitian sebelumnya yang dilakukan oleh Bachtiar dkk. tahun 2015 yang menunjukkan bahwa masih ditemukan mahasiswa yang mengkonsumsi sayur dan buah belum sesuai anjuran dari segi jumlah porsi dan frekuensi baik pada mahasiswa gizi maupun non gizi di Poltekkes Kemenkes Tasikmalaya. ${ }^{10}$

Berdasakan latar belakang di atas maka tujuan penelitian ini adalah untuk mengetahui hubungan ketersediaan dan kesukaan dengan konsumsi buah dan sayur pada Mahasiswa Poltekkes Kemenkes Tasikmalaya.

\section{METODE}

Penelitian ini sudah mendapat persetujuan etik penelitian kesehatan dari Komisi Etik Peneltian Kesehatan (KEPK) Politeknik Kesehatan Kemenkes Bandung No. 12/KEPK/PE/VIII/2017. Jenis Penelitian ini adalah observasional dengan desain cross sectional, untuk mengetahui hubungan antara variabel terikat dan variabel bebas. 
Penelitian ini dilaksanakan pada bulan Agustus - November tahun 2017 di Kampus Poltekkes Kemenkes Tasikmalaya. Populasi adalah semua mahasiswa Poltekkes Kemenkes Tasikmalaya. Sampel penelitian ini adalah mahasiswa Poltekkes Kemenkes Tasikmalaya yang berada di Kampus Wilayah Tasikmalaya (Prodi DIII/DIV Kebidanan Tasikmalaya, Prodi DIII Keperawatan Tasikmalaya, Prodi DIII/DIV Keperawatan Gigi, Prodi DIII Gizi Tasikmalaya, Prodi DIII Farmasi dan Prodi DIII Perekam dan Informasi Kesehatan Tasikmalaya Tahun Ajaran 2016/2017). Besar sampel minimal sebanyak 108 orang dipilih berdasarkan rumus besar sampel minimal uji hipotesis dua proporsi populasi menurut Lemeshow dkk. tahun 1997. ${ }^{11}$

Teknik penarikan sampel yang digunakan adalah proporsional stratified random sampling, dengan cara populasi dalam hal ini Mahasiswa Poltekkes Kemenkes Tasikmalaya dibagi-bagi terlebih dahulu menjadi kelompok yang relatif homogen untuk menjamin keterwakilan dari masing-masing yang kemudian dipilih secara acak termasuk jenis kelamin.

Pemilihan sampel yang digunakan tersebut di atas tetap mempertimbangkan kesediaan responden untuk mengikuti penelitian (Pengisian PSP) dalam upaya perlindungan subyek penelitian yang bersifat tidak memaksa dan terjaga keharasiaan data tersebut. Variabel penelitian ini adalah ketersediaan, kesukaan dan konsumsi buah sayur. Konsumsi buah dan sayur adalah jumlah konsumsi buah dan sayur yang dikonsumsi baik dalam keadaan mentah atau olahannya, bentuk padat maupun cair, setiap kali konsumsi dari ukuran rumah tangga yang dikonversi ke dalam ukuran berat (gram) per hari selama satu tahun terakhir, menggunakan Semi Kuantitatif Food Frequency Questionnare (FFQ). Kemudian hasil dikategorisasi menjadi baik, jika $\geq 400$ gram / hari dan kurang, jika < 400 gram / hari. Ketersediaan adalah kemudahan responden untuk mendapatkan buah dan sayur di rumah / kost / kampus / sekitarnya dan pada saat belajar / mengerjakan tugas / bermain / waktu luang menggunakan alat ukur berupa kuesioner terstruktur. Kesukaan adalah penilaian rasa suka terhadap buah dan sayur menggunakan alat ukur berupa kuesioner terstruktur. Pengolahan dan analisis data univariat untuk melihat distribusi frekuensi karakteristik subjek penelitian, sedangkan analisis bivariat digunakan untuk melihat apakah terdapat hubungan antar variabel dengan chi square test. Uji chi square digunakan untuk data yang bersifat kategorik. Jika tidak adanya nilai expected yang kurang dari lima maka menggunakan Fisher exact test.

\section{HASIL}

Tabel 1. Distribusi Karakteristik, Kesukaan dan Ketersediaan Konsumsi Buah Sayur Pada Mahasiswa Poltekkes Kemenkes Tasikmalaya

\begin{tabular}{|c|c|c|}
\hline Variabel & $\mathbf{n}$ & $\%$ \\
\hline \multicolumn{3}{|l|}{ Jenis Kelamin } \\
\hline Laki-Laki & 10 & 9,3 \\
\hline Perempuan & 98 & 90,7 \\
\hline \multicolumn{3}{|l|}{ Umur } \\
\hline 18 tahun & 5 & 4,6 \\
\hline 19 tahun & 56 & 51,9 \\
\hline 20 tahun & 47 & 43,5 \\
\hline \multicolumn{3}{|l|}{ Tempat Tinggal } \\
\hline Rumah & 21 & 19,4 \\
\hline Kost & 87 & 80,6 \\
\hline \multicolumn{3}{|l|}{ Jarak } \\
\hline Dekat & 70 & 64,8 \\
\hline Jauh & 38 & 35,2 \\
\hline \multicolumn{3}{|l|}{ Lokasi } \\
\hline Warung & 37 & 34,3 \\
\hline Pedagang Keliling & 32 & 29,6 \\
\hline Pasar & 26 & 24,1 \\
\hline Mini Market & 1 & 9 \\
\hline Super Market & 12 & 11,1 \\
\hline \multicolumn{3}{|l|}{$\begin{array}{l}\text { Ketersediaan } \\
\text { Buah Sayur }\end{array}$} \\
\hline Baik & 52 & 48,1 \\
\hline Kurang & 56 & 51,9 \\
\hline \multicolumn{3}{|l|}{$\begin{array}{l}\text { Kesukaan Buah } \\
\text { Sayur }\end{array}$} \\
\hline $\mathrm{Ya}$ & 100 & 92,6 \\
\hline Tidak & 8 & 7,4 \\
\hline \multicolumn{3}{|l|}{$\begin{array}{l}\text { Konsumsi } \\
\text { BuahSayur }\end{array}$} \\
\hline Baik ( $\geq 400$ gram) & 66 & 61,1 \\
\hline $\begin{array}{l}\text { Kurang ( }<400 \\
\text { gram) }\end{array}$ & 42 & 38,9 \\
\hline
\end{tabular}


Proporsi mahasiswa yang berjenis kelamin perempuan lebih besar dibandingkan mahasiswa berjenis kelamin laki-laki yaitu 90,7\%. Proporsi umur terbanyak adalah 19 tahun yaitu sebesar $51,9 \%$. Lebih banyak responden yang tinggal di tempat kost dibandingkan tinggal di rumah yaitu sebesar $80,6 \%$. Sebanyak $64,8 \%$ responden memiliki jarak yang dekat dengan akses untuk memperoleh buah dan sayur. Responden mendapatkan akses buah dan sayur paling banyak dari warung (34,3\%). Ketersediaan buah dan sayur kurang sebesar 51,9\%. Hampir semua responden (92,6\%) menyatakan menyukai buah dan sayur. Sebagian besar mahasiswa sudah mengonsumsi buah sayur sesuai anjuran $(61,1 \%)$.

Tabel 3. Hubungan Kesukaan dengan Konsumsi Buah dan Sayur Mahasiswa Poltekkes Kemenkes Tasikmalaya Tahun 2017

\begin{tabular}{cccccccc}
\hline & \multicolumn{2}{c}{$\begin{array}{c}\text { Konsumsi Buah dan Sayur } \\
\text { Baik }\end{array}$} & $\begin{array}{c}\text { Kurang } \\
(\geq 400 \text { gram/hari })\end{array}$ & \multicolumn{2}{c}{ Total } & $p$ \\
& $(<4$ gram/hari $)$ & & & \\
\hline Kesukaan Buah dan Sayur & $\mathrm{n}$ & $\%$ & $\mathrm{n}$ & $\%$ & $\mathrm{~N}$ & $\%$ & \\
\hline Ya & 64 & 96,97 & 36 & 85,71 & 100 & 92,59 & 0,05 \\
Tidak & 2 & 3,03 & 6 & 14,29 & 8 & 7,41 & \\
\hline Jumlah & 66 & 100 & 42 & 100 & 108 & 100 & \\
\hline
\end{tabular}

Hasil analisis Fisher exact test pada Tabel 3 menunjukkan tidak hubungan yang bermakna antara kesukaan buah dan sayur pada
Mahasiswa Poltekkes Kemenkes Tasikmalaya dengan konsumsi buah dan sayur ( $p$ value $=0,05)$.

Tabel 4. Hubungan Ketersediaan dengan Konsumsi Buah Sayur Mahasiswa Poltekkes Kemenkes Tasikmalaya Tahun 2017

\begin{tabular}{cccccccc}
\hline & \multicolumn{2}{c}{$\begin{array}{c}\text { Konsumsi } \\
\text { Baik }\end{array}$} & $\begin{array}{c}\text { Buah Sayur } \\
\text { Kurang } \\
\text { gram/hari })\end{array}$ & \multicolumn{2}{c}{ Total } & $p$ \\
& $(<400$ gram/hari $)$ & & & \\
\hline Ketersediaan Buah dan Sayur & $\mathrm{n}$ & $\%$ & $\mathrm{n}$ & $\%$ & $\mathrm{n}$ & $\%$ & \\
\hline Baik & 43 & 65,15 & 9 & 21,43 & 52 & 48,15 & 0,00 \\
Kurang & 23 & 34,85 & 33 & 78,57 & 56 & 51,85 & \\
\hline Jumlah & 66 & 100 & 42 & 100 & 108 & 100 & \\
\hline
\end{tabular}

Tabel 4 menyajikan hasil analisis statistik uji chi square. Hasil menunjukkan $p$ value $<0,00$ artinya terdapat hubungan bermakna antara ketersediaan dengan konsumsi buah dan sayur pada Mahasiswa Poltekkes Kemenkes Tasikmalaya Tahun 2017.

\section{PEMBAHASAN}

Sebagian besar $(61,1 \%)$ mahasiswa Poltekkes Tasikmalaya sudah mengonsumsi buah dan sayur sesuai anjuran yaitu sebanyak 400 gram setiap hari, dimana konsumsi sayur sebanyak 250 gram dan konsumsi buah sebanyak 150 gram. Namun masih ditemukannya beberapa mahasiswa $(38,9 \%)$ yang konsumsi sayur dan buah belum sesuai anjuran. Pemilihan makanan yang akan konsumen makan didasari oleh berbagai kriteria, salah satunya adalah preferensi atau kesukaan, yang masing- 
masing individu memiliki perbedaan dalam hal kesukaan. Alasan responden suka terhadap buah dan sayur karena beranggapan untuk menjaga kesehatan. Hasil penelitian pada Mahasiswa Politeknik di Ghana menunjukkan Jenis kelamin laki-laki secara signifikan lebih menyukai jeruk, pisang dan nanas, sedangkan mahasiswa perempuan lebih menyukai blackberry, anggur, okra, cabe hijau dan lettuce. ${ }^{13}$ Berdasarkan hasil wawancara pada responden penelitian, jenis buah dan sayur yang disukai oleh Mahasiswa Poltekkes Tasikmalaya sangat beragam. Jenis sayuran yang paling disukai adalah bayam, wortel dan kangkung, sedangkan jenis buah paling disukai adalah mangga, anggur dan alpukat.

Hasil penelitian ini secara statistik menunjukkan tidak adanya hubungan antara kesukaan buah dan sayur dengan konsumsi pada mahasiswa. Namun secara teori bahwa faktor preferensi sayur buah berpengaruh secara positif dan signifikan terhadap konsumsi sayur buah. ${ }^{14}$ Sejalan dengan hal tersebut, Chu et al. pada tahun 2013 melaporkan bahwa anak yang menyukai buah dan sayur secara signifikan berhubungan dengan asupan yang tinggi daripada yang tidak suka. ${ }^{15}$ Sehingga fokus intervensi kedepan dapat melalui peningkatan kesukaan, salah satunya dengan cara mengenalkan buah dan sayur secara lokal dan meluas agar diterima.

Faktor yang mempengaruhi pola konsumsi buah dan sayur selain tingkat kesukaan juga ketersediaan buah dan sayur di keluarga. Jenis makanan yang tersedia mempunyai peluang yang lebih besar untuk dikonsumsi. Sehingga perlunya upaya penyediaan buah dan sayur di rumah, di sekolah dan area sekitarnya dalam rangka peningkatan jenis makanan ini. ${ }^{16}$ Ketersediaan bahan makanan utamanya buah dan sayur juga sangat dipengaruhi oleh faktor lingkungan, karena adanya jenis buah yang bersifat musiman dan akan berpengaruh pada harga bahan makanan tersebut. ${ }^{17}$ Hasil penelitian ini menunjukkan adanya hubungan antara ketersediaan dengan konsumsi buah dan sayur pada mahasiswa, sehingga disarankan adanya upaya intervensi terhadap lingkungan keluarga berupa ketersediaan buah dan sayur sebagai upaya peningkatan konsumsi.
Ketersediaan buah dan sayur di lingkungan asrama dan kantin sekolah juga dapat mendukung penghuninya dalam mengonsumsi buah dan sayur. ${ }^{18}$ Hasil penelitian Aggarwal et al. pada tahun 2014 tentang tempat pemilihan pembelian buah dan sayur, menunjukkan konsumsi buah dan sayur tidak berhubungan dengan jarak tetapi berdasarkan tempat pembelian, seperti di pasar atau supermarket kecil dan besar. ${ }^{19}$ Pada penelitian ini lebih dari setengah $(64,8 \%)$ responden memiliki jarak yang dekat untuk mengakses buah dan sayur. Adapun tempat yang paling banyak dikunjungi oleh responden untuk memperoleh buah dan sayur adalah warung.

\section{SIMPULAN DAN SARAN}

Simpulan penelitian ini adalah sebanyak $61,1 \%$ Mahasiswa Poltekkes Kemenkes Tasikmalaya mengonsumsi buah dan sayur sesuai anjuran ( $\geq 400$ gram/hari) dan sebanyak $38,9 \%$ belum sesuai anjuran ( $\geq 400$ gram/hari). Tidak adanya hubungan antara kesukaan dengan konsumsi buah dan sayur. Adanya hubungan antara ketersediaan dengan konsumsi buah dan sayur pada Mahasiswa Poltekkes Kemenkes Tasikmalaya. Saran dari penelitian ini adalah perlunya upaya peningkatan ketersediaan buah sayur di keluarga serta peningkatan kesukaan, melalui pengenalan buah dan sayur.

\section{DAFTAR PUSTAKA}

1. Kementerian Kesehatan RI (Bina Gizi dan KIA). Pedoman Gizi Seimbang. Jakarta; 2014

2. Dehghan, M., N. Akhtar-Danesh and A. T. Merchant. Factors Associated with Fruit and Vegetable Consumption among Adults. The British Dietetic Association Jurnal Human Nutrition Dietetic. 2011; 128-134

3. Departemen Kesehatan RI (Badan Penelitian dan Pengembangan). Riset Kesehatan Dasar Laporan Nasional 2007. Jakarta; 2008 
4. Kementerian Kesehatan RI (Badan Penelitian dan Pengembangan Kesehatan) Riset Kesehatan Dasar 2013. Jakarta; 2013

5. Kementerian Kesehatan RI (Badan Penelitian dan Pengembangan Kesehatan) Studi Diet Total Survei Konsumsi Makanan Individu Indonesia. Jakarta; 2014

6. Rasmussen, M., Rikke K., Knut-Inge K., Lesliye L., Johannes B., Elling B., and Pernille D. Determintants Of Fruit dan (5) 615-626

8. Vabo, Mette and Havard Hansen. The Relationship Between Food Preferences and Food Choices: A Theoritical Discussion. International Journal of Business and Social Science. 2014; 5 (7) 145-157

9. FAO. Promotion of Fruit and Vegetable Health Report of the Pacific Regional Workshop. 2015; 1- 81

10. Bachtiar, A. Sumarto, I. Karimah dan I. Nuraeni. Pengetahuan, Pengeluaran dan Konsumsi Sayur Buah pada Mahasiswa Gizi dan Non-Gizi Poltekkes Kemenkes Tasikmalaya. Buletin Media Informasi. 2016; Vol 12 (1), pp 67-76

11. Lemeshow, S., D. W. Hosmer Jr., J. Klar, dan S.K. Lwanga. Besar Sampel Dalam Penelitian Kesehatan, Yogyakarta: Gadjah Mada University Press. 1997; 1520

12. Geissler, C. and Hillary Power. Human Nutrition 1 th Edition. London: Elsevier Churchill Liviingstone; 2005.

13. Kpodo, Mensah, dan Dzah. Fruit and Vegetable Consumption Patterns and Preferences of Students in Ghanaian Polytechnic. World Jurnal of Nutrition and Health. 2015; 3 (3) 53-59

14. Granner, M. and Alexandra E. Evans. Variables Associated With Fruit and
Vegetable Consumption Among Children and Adolescents: A Review of The Literature, Part 1: Quantitatife Studies. International Journal of Behavioral Nutrition and Physical Activity. 2006; 3 (22) 1-19

7. Cullen, K.W., T. Baranowski, E. Owens, T. Marsh, R. Rittenberry and Carl de Moor. Availability, Accesibility, and Preference for Fruit, 100\% fruit Juice and Vegetables Influence Children Dietary's Dietary Behaviour. Health Education and Behaviour. 2003; 30 Vegetableintake in Adolescents. Am J Health Behav. 2011; 35 (5) 591-602.

15. Chu, Yen Li, Ana Farmer, C. Fung, S. Kuhle, P. Veugelers. Fruit and Vegetable Preferences and Intake Among Children in Alberta Canadian Journal of Dietetic Practice and Research. 2013; 74 (1) 21 37

16. Dewantari, N. Made dan A. Widiani. 2011. Fruits and Vegetables Consumption Pattern In School Children. Jurnal Skala Husada. 2011; 8 (2) 119-125

17. Reynolds, Kim. et.al. Pattern Child and Adolescent Consumption of Fruit and Vegetables. Effect of Gender and Ethnicity across four sites. Journal of the American College of Nutrition. 1999; 18 (2) 248-254

18. Nenobanu, A. I., M.D. Kurniasari, dan M. Rahardjo. Faktor-faktor yang berhubungan dengan Perikaku Konsumsi Buah dan Sayur pada Mahasiswi Asrama Universitas Kristen Satya Wacana. Indonesian Journal on Medical Science. 2018; 5 (1) 95-103

19. Aggarwal, A., Andrea J. Cook, Junfeng Jiao, Rebecca A. Seguin,, Anne Vernez Moudon, Philip M. Hurvitz, and Adam Drewnowski. Socioeconomic Access to Supermarkets and Fruit and Vegetable Consumption. American Journal of Public Health. 2014; 104 (5) 197 